\title{
PI3K-Akt-mTOR signal inhibition affects expression of genes related to endoplasmic reticulum stress
}

\author{
Q. Song, C.C. Han, X.P. Xiong, F. He, W. Gan, S.H. Wei, H.H. Liu, \\ L. Li and H.Y. Xu
}

Farm Animal Genetic Resources Exploration and Innovation Key Laboratory of Sichuan Province, Sichuan Agricultural University, Chengdu, Sichuan, China

Corresponding author: C.C. Han

E-mail: chunchunhai_510@163.com

Genet. Mol. Res. 15 (3): gmr.15037868

Received October 21, 2015

Accepted January 18, 2016

Published July 25, 2016

DOI http://dx.doi.org/10.4238/gmr.15037868

Copyright $(\subset 2016$ The Authors. This is an open-access article distributed under the terms of the Creative Commons Attribution ShareAlike (CC BY-SA) 4.0 License.

\begin{abstract}
PI3K-Akt-mTOR signaling pathway is associated with endoplasmic reticulum (ER) stress. However, it is not clear how this signaling pathway affects the ER stress. The present study aimed to determine whether the PI3K-Akt-mTOR signaling pathway regulates tunicamycin (TM)-induced increases in mRNA levels of genes involved in the ER stress, to help elucidate the mechanism by which this pathway affects the ER stress in primary goose hepatocytes. Primary hepatocytes were isolated from geese and cultured in vitro. After $12 \mathrm{~h}$ in a serumfree medium, the hepatocytes were incubated for $24 \mathrm{~h}$ in a medium with either no addition (control) or with supplementation of TM or TM together with PI3K-Akt-mTOR signaling pathway inhibitors (LY294002, rapamycin, NVP-BEZ235). Thereafter, the expression levels of genes involved in the ER stress (BIP, EIF2a, ATF6, and $X B P 1)$ were assessed. The results indicated that the mRNA level of $B I P$
\end{abstract}


was up-regulated in $0.2,2$, and $20 \mu \mathrm{M} \mathrm{TM}$ treatment group $(\mathrm{P}<0.05)$, whereas the mRNA levels of EIF2a, ATF6, and XBP1 were up-regulated in the $2 \mu \mathrm{M}$ TM treatment group $(\mathrm{P}<0.05)$. However, the TM mediated induction of mRNA levels of genes involved in the ER stress (BIP, $E I F 2 a, A T F 6$, and $X B P 1$ ) was down-regulated after the treatment with PI3K-Akt-mTOR pathway inhibitors (LY294002, NVP-BEZ235, and rapamycin). Therefore, our results strongly suggest that the PI3K-AktmTOR signaling pathway might be involved in the down-regulation of the TM-induced ER stress in primary goose hepatocytes.

Key words: Endoplasmic reticulum (ER) stress; Tunicamycin (TM); Goose primary hepatocytes; Unfolded protein response (UPR); PI3k-Akt-mTOR signaling pathways

\section{INTRODUCTION}

The endoplasmic reticulum (ER) plays an important role in various cellular processes including cellular homeostasis, development, synthesis and processing of proteins and their glycosylation, and stress responsiveness. It provides a site for protein modification and folding as well as functions as an intracellular $\mathrm{Ca}^{2+}$ store that plays a central role in signal transduction (Galligan et al., 2012; Pagliassotti, 2012). However, when oxidative stress, chemical toxicity, hepatic viral infections, metabolic disorders, and abuse of alcohol or drugs cause accumulation of unfolded proteins in the ER lumen and disrupt the intracellular $\mathrm{Ca}^{2+}$ homeostasis (Lai et al., 2003; Rao et al., 2004; Schröder and Kaufman, 2005b), ER stress occurs. In order to restore ER homeostasis, liver cells down-regulate the overall protein synthesis through an adaptive protective response termed the unfolded protein response (UPR) signaling system, which involves enhancement of protein folding and degradation in the ER (Shen et al., 2004). Perturbations in the environment within the ER lumen, for example a reduction in the luminal $\mathrm{Ca}^{2+}$ concentration or altered redox status, can affect protein folding and processing (Darling and Cook, 2014).

The UPR in mammalian cells is composed of three distinct signaling pathways, which are initiated by three ER transmembrane sensors, inositol-requiring enzyme 1 (IRE1), doublestranded RNA-dependent protein kinase-like ER kinase (PERK), and activating transcription factor 6 (ATF6; Schröder and Kaufman, 2005a). Activation of these sensors is dependent on the dissociation of the major ER chaperone BiP/GRP78 (binding immunoglobulin protein/ glucose regulated protein 78; Hendershot, 2004). When ER stress homeostasis is perturbed, the chaperone $\mathrm{BiP} / \mathrm{GRP} 78$ interacts with unfolded proteins leading to the activation of the three implicated ER transmembrane proteins, thereby activating the UPR.

PI3K/Akt/mTOR pathway plays an important role in signal transduction pathways including those for cell growth, proliferation, survival, and metabolism. Akt (Protein Kinase B) counteracts ER stress-induced cell death (Hu et al., 2004). The cerebral ischemic post conditioning suppression of ER stress is mediated by the PI3K/Akt pathway (Yuan et al., 2011). The mammalian target of rapamycin (mTOR), a coordinator between nutritional stress and cellular growth machinery, is associated with ER stress. This suggests that the activation of the UPR pathway is an important consequence of mTORC1 activation (Li et al., 2014a). Conversely, mTORC1 can also be activated by ER stress (Flamment et al., 2012). However, how the PI3K-Akt-mTOR signaling pathway affects the ER stress, remains unclear.

Genetics and Molecular Research 15 (3): gmr.15037868 
Therefore, in the present study, we investigated whether the inhibition of PI3K-AktmTOR signaling would affect the TM-induced alterations in the mRNA levels of genes involved in ER stress in primary cultures of goose hepatocytes. We hope that the results will help in elucidating the mechanism of the effect of PI3K-Akt-mTOR signaling pathway on ER stress.

\section{MATERIAL AND METHODS}

\section{Ethics statement}

All the animal studies were approved by the Animal Care and Use Committee of Sichuan Agricultural University in China.

\section{Isolation and culture of goose primary hepatocytes}

Hepatocytes were isolated from three 30-day-old Sichuan White geese, procured from the Experimental Farm for Waterfowl Breeding at Sichuan Agricultural University, using a modification of the "two-step procedure" described by Seglen (1976). The modification involved the removal of the goose liver before the preperfusion step. The geese were cleaned with a disinfectant and were administered $100 \mathrm{IU} / \mathrm{kg}$ body weight heparin sodium by intravenous injection. Thereafter, anesthesia was induced by intraperitoneal injection with $3 \%$ isoflurane (35 mg/kg body weight). After the geese fell into coma, their abdominal cavity was slit along the median line of abdomen and liver was taken out rapidly and cleaned with physiological salt solution at $37^{\circ} \mathrm{C}$. The remaining steps were same as in the two-step procedure. Cell viability was greater than $90 \%$, as assessed by trypan blue dye exclusion test. Freshly isolated hepatocytes were diluted to $1 \times 10^{6}$ cells $/ \mathrm{mL}$. The culture medium used was dulbecco's modified eagle's medium (DMEM) (containing $4.5 \mathrm{~g} / \mathrm{L}$ glucose; GIBCO, USA), which was supplemented with $100 \mathrm{IU} / \mathrm{L}$ insulin (Sigma, $86 \mathrm{USA}$ ), $100 \mathrm{IU} / \mathrm{mL}$ penicillin (Sigma, USA), $100 \mathrm{~g} / \mathrm{mL}$ streptomycin (Sigma, USA), $2 \mathrm{mM}$ glutamine (Sigma, USA), and $100 \mathrm{~mL} / \mathrm{L}$ fetal bovine serum (Clark, Australia). The goose hepatocytes were plated in 60-mm culture dishes at a density of $3 \times 10^{6}$ cells per dish for total RNA isolation. The cultures were incubated at $4^{\circ} \mathrm{C}$ in a humidified atmosphere containing $5 \% \mathrm{CO}_{2}$ and the media was renewed after $3 \mathrm{~h}$ followed by the addition of serum-free media after $24 \mathrm{~h}$. After an additional $12 \mathrm{~h}$, the cells were separately treated with serum-free media supplemented with $0,0.2,2$, and $20 \mu \mathrm{M}$ TM (Sigma, USA) for $12 \mathrm{~h}$, whereas the control cells were cultured with un-supplemented serum-free media for $12 \mathrm{~h}$ or media supplemented with 0 , $0.2,2$, and $20 \mu \mathrm{M} \mathrm{TM}$ and incubated for $24 \mathrm{~h}$ (the serum-free medium supplemented with TM was not renewed), while the control cells were cultured with serum-free media for $24 \mathrm{~h}$ (serumfree media was renewed every $24 \mathrm{~h}$ ), or supplemented with $0,0.2,2$, and $20 \mu \mathrm{M}$ of TM and incubated for $36 \mathrm{~h}$ (the serum-free media supplemented with TM was not renewed), while the control cells were cultured with serum-free media for $36 \mathrm{~h}$. In a similar way, the cells were treated with inhibitors (LY294002; NVP-BEZ235; rapamycin) at different concentrations (LY294002: 0, 10, 20, 30, 40, $50 \mu \mathrm{M}$; NVP-BEZ235: 0, 0.1, 1, 10, 500, 1000, $2000 \mathrm{nM}$; rapamycin: 0, 1, $10,30,50,90 \mathrm{nM}$ ) for $6,12,24$, and $36 \mathrm{~h}$. Additionally, some cells were treated with serumfree media supplemented with PI3K-Akt-mTOR pathway inhibitors (LY294002: $20 \mu \mathrm{M}$; NVPBEZ235: $1000 \mathrm{nM}$; rapamycin: $30 \mathrm{nM}$, respectively), followed by the addition of $2 \mu \mathrm{M}$ TM and incubation for $24 \mathrm{~h}$. At the end of the incubation period, the culture media and cells were cooled on ice and collected. All the experiments were repeated three times.

Genetics and Molecular Research 15 (3): gmr.15037868 


\section{Cell viability assay}

To determine the effect of TM on the viability of goose primary hepatocytes, the cells were treated with $\mathrm{TM}$ at different concentrations $(0,0.2,2$, and $20 \mu \mathrm{M})$ for 12,24 , and $36 \mathrm{~h}$. To determine the effect of inhibitors on goose primary hepatocyte viability, the cells were treated with inhibitors at different concentrations (LY294002: 0, 10, 20, 30, 40, 50 $\mu \mathrm{M}$; NVP-BEZ235: 0, 0.1, 1, 10, 500, 1000, $2000 \mathrm{nM}$; rapamycin: 0, 1, 10, 30, 50, $90 \mathrm{nM}$ ) for $6,12,24$, and $36 \mathrm{~h}$. Cell viability was determined using CCK-8 dye (Beyotime Institute of Biotechnology, China) according to manufacturer's instructions. In brief, $0.5 \times 10^{4}$ cells/ well were seeded in a 96-well plate, and the cultures were incubated at $4^{\circ} \mathrm{C}$ in a humidified atmosphere containing 5\% $\mathrm{CO}_{2}$. The medium was renewed after $3 \mathrm{~h}$ followed by the addition of serum-free medium after $24 \mathrm{~h}$. Subsequently, cells were treated with TM for 12, 24, and 36 h. Thereafter, $10 \mu \mathrm{L} \mathrm{CCK}-8$ dye was added to each well, cells were incubated at $37^{\circ} \mathrm{C}$ for $2 \mathrm{~h}$, and the absorbance was determined at $450 \mathrm{~nm}$ using a microplate reader.

\section{Isolation of total RNA and real-time polymerase chain reaction (RT-PCR)}

Total RNA was extracted using Trizol (Invitrogen, USA) and was reverse-transcribed using the Primer Script ${ }^{\mathrm{TM}}$ RT system kit for real-time polymerase chain reaction (RT-PCR; TaKaRa, Japan) as per the manufacturer instructions. The RT-PCR mixture contained SYBR Premix Ex Taq ${ }^{\mathrm{TM}}$ (TaKaRa, Japan), the newly generated cDNA template, primers for the target genes, and sterile water. The RT-PCR was performed on the on a thermocycler (Bio-Rad, USA) using the following cycling parameters: one cycle at $95^{\circ} \mathrm{C}$ for $10 \mathrm{~s}$, followed by 40 cycles at $95^{\circ} \mathrm{C}$ for $5 \mathrm{~s}$ and $60^{\circ} \mathrm{C}$ for $40 \mathrm{~s}$. For each experimental sample, a normalized target gene level, corresponding to the relative expression of the target gene with respect to the housekeeping genes, $\beta$-actin and $18 \mathrm{~S}$ rRNA, was determined by the $2^{-\Delta \Delta \mathrm{Ct}}$ method, as described previously (Livak and Schmittgen, 2001). Specific primers used for the amplification are listed in Table 1; they were designed according to the sequences determined in our lab for the genes ATF6 (GenBank accession No. KT900002), EIF2a (GenBank accession No. KT900003), XBP1 (GenBank accession No. KT900004); BIP (GenBank accession No. KT900005); $18 S$ (GenBank accession No. L21170), and $\beta$-actin (GenBank accession No: M26111.1).

Table 1. Primer sequences for real-time PCR.

\begin{tabular}{l|l|c}
\hline Gene name & Primer sequence $\left(5^{\prime}-3^{\prime}\right)$ & Product size (bp) \\
\hline$B I P$ upstream & TGTAAATGGAATCCTCCGTGTCA & 87 \\
\hline$B I P$ downstream & TCCGCAAACTTCTCAGCATCAT & 94 \\
\hline$E I F 2 a$ upstream & TTCCATAGCATTGTCACCTTGTCG & 81 \\
\hline$E I F 2 a$ downstream & CCAGGAGCACAGCCAACCAA & 82 \\
\hline$A T F 6$ upstream & GGAGCACCACCGATTGACCTT & 92 \\
\hline$A T F 6$ downstream & GGCTCAGGCTAACATTGGCATC & 129 \\
\hline$X B P 1$ upstream & AATGGGCAACCAAACCAATATG & \\
\hline$X B P 1$ downstream & GGCTGCAAGGCTACAAGGAGA & \\
\hline$\beta$ - $a$ tin upstream & CAACGAGCGGTTCAGGTGT & \\
\hline$\beta$ - ctin downstream & TGGAGTTGAAGGTGGTCTCG & \\
\hline $18 S$ upstream & TTGGTGGAGCGATTTGTC & \\
\hline $18 S$ downstream & ATCTCGGGTGGCTGAACG & \\
\hline
\end{tabular}

\section{Statistical analyses}

The data were subjected to ANOVA testing and the means were assessed for

Genetics and Molecular Research 15 (3): gmr.15037868 
significance by the Tukey test. Analysis of variance and $t$-tests were performed using the SAS 9.13 package (SAS Institute Inc, Cary, NC, USA). The results are reported as means \pm SD. $\mathrm{P}<0.05$ was accepted as the level of significance. Every experiment was repeated with 3 biological samples, and each sample was run in triplicate.

\section{RESULTS}

\section{TM induced ER stress}

Cell viability was evaluated through the CCK-8 assay. As shown in Figure 1, there was no serious damage to cell viability after TM treatment for $12 \mathrm{~h}(\mathrm{P}<0.05)$. Compared to the untreated cells, the cell viability was decreased in a dose- and time-dependent manner after TM treatment for $24(\mathrm{P}<0.01)$ or $48 \mathrm{~h}(\mathrm{P}<0.05)$. As shown in Figure 2, after a 24-h treatment, $0.2,2$, and $20 \mu \mathrm{M}$ TM up-regulated the mRNA level of BIP $(\mathrm{P}<0.05)$, and the mRNA level of BIP reached the highest after culture with $2 \mu \mathrm{M}$ TM. Thus, $2 \mu \mathrm{M}$ TM was chosen as the suitable concentration to induce ER stress. As shown in Figure 3, after the cells were treated with $2 \mu \mathrm{M}$ TM for $24 \mathrm{~h}$, the mRNAs of genes (BIP, EIF2a, ATF6, and XBPI) involved in ER stress were up-regulated in the goose primary hepatocytes $(\mathrm{P}<0.05)$.

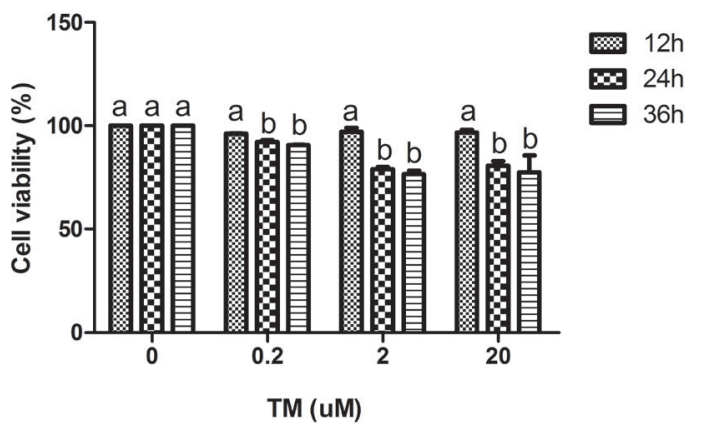

Figure 1. Effect of tunicamycin (TM) on cell viability. Cell viability was determined after incubation with different concentrations of TM for 12,24 , and 36 h by the CCK- 8 assay. Data are reported as means \pm SD $(\mathrm{N}=3)$. Different lowercase letters in the same set indicate the differences among the treatments at $\mathrm{P}<0.05$, compared to the 12-h group.

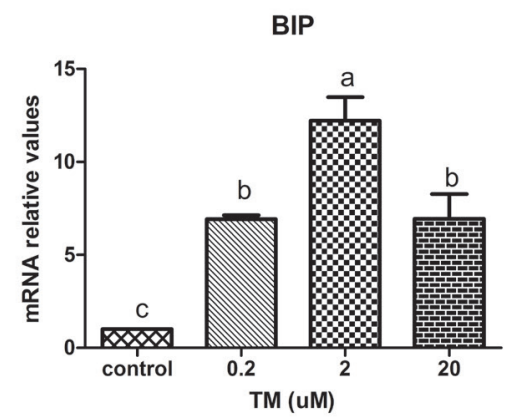

Figure 2. Effect of different concentrations of tunicamycin (TM) on the mRNA expression of BIP. The mRNA levels were tested by real-time polymerase chain reaction after treatment with $0.2,2$, or $20 \mu \mathrm{M} \mathrm{TM}$ for $24 \mathrm{~h}$. The expression of genes without the treatment was normalized to a value of 1 . Different lowercase letters in the same set indicate the differences among the treatments at $\mathrm{P}<0.05$.

Genetics and Molecular Research 15 (3): gmr.15037868 

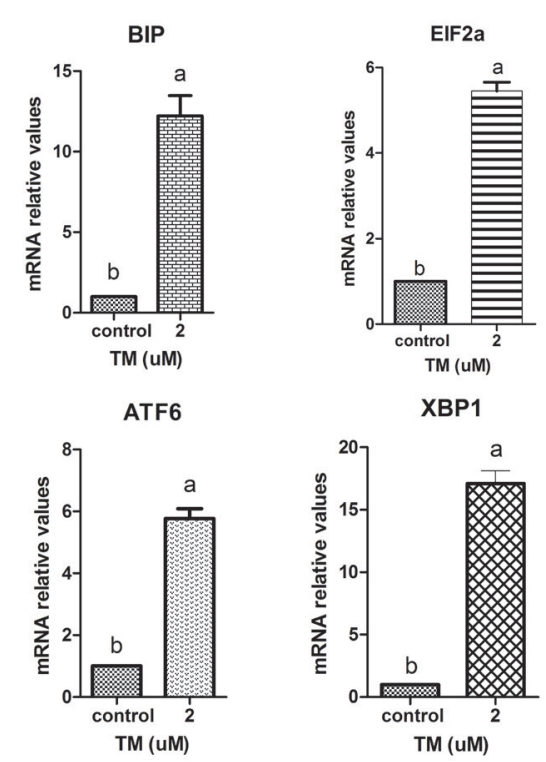

Figure 3. Effect of tunicamycin (TM) on the mRNA expression of genes involved in ER stress. The mRNA levels were tested by real-time polymerase chain reaction after treatment with $2 \mu \mathrm{M} \mathrm{TM}$ for $24 \mathrm{~h}$. The expression of genes without any treatment was normalized to a value of 1 . Different lowercase letters in the same set indicate the differences among the treatments at $\mathrm{P}<0.05$.

\section{Effect of LY294002, NVP-BEZ235, or Rapamycin on cell viability}

Cell viability after treatment with inhibitors of PI3K-AKT-mTOR signaling pathways was evaluated through the CCK-8 assay. As shown in Figure 4, LY294002 at concentrations of $1,10,20,30,40$, or $50 \mu \mathrm{M}$ decreased the cell viability compared to the control group. The cell viability showed a downward trend with an increasing LY294002 concentration. The cell viability showed a decreasing trend in hepatocytes treated with rapamycin at concentrations of $1,10,30,50$, and $90 \mathrm{nM}$ compared to those in the control group. NVP-BEZ235 at concentrations of $0.1,1,10,500,1000$, and $2000 \mathrm{nM}$ decreased the cell viability compared to the control group in a concentration dependent manner. For use in our experiments, we determined the suitable concentration of inhibitors to be $20 \mu \mathrm{M}, 1000 \mathrm{nM}$, and $30 \mathrm{nM}$ for LY294002, NVPBEZ235, and rapamycin, respectively; these inhibitors play an important restraining role in the PI3K-AKT-mTOR signaling pathways.

\section{LY294002 abrogated TM-induced ER stress}

To verify that the regulation of ER stress was linked to the PI3K signaling pathway, the mRNA level of key genes involved in ER stress was evaluated in cells co-treated with TM and a PI3K signaling inhibitor, LY294002. As shown in Figure 5, after the combined treatment with $2 \mu \mathrm{M}$ TM and LY294002, the mRNA levels of genes were significantly lower than in the treatment with $2 \mu \mathrm{M}$ TM alone. These results indicated that LY294002 abrogated the TMinduced ER stress and that the PI3K signaling pathway might down-regulate ER stress in the goose primary hepatocytes. 

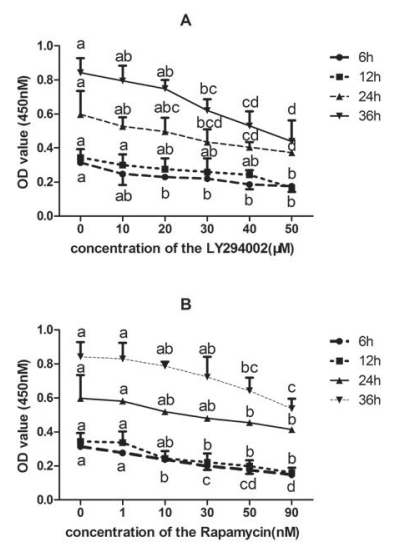

c

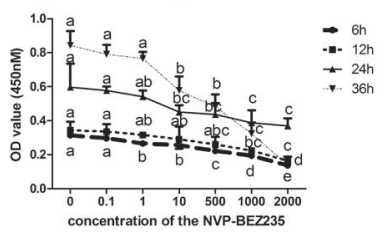

(nM)

Figure 4. Cell viability after incubation with different concentrations of LY294002, NVP-BEZ235, or rapamycin for $6,12,24$, and $36 \mathrm{~h}$ as determined by the CCK-8 assay. A. Dose and time response of cell viability to LY294002. B. Dose and time response of cell viability to rapamycin. C. Dose and time response of cell viability to NVP-BEZ235. Data are reported as means $\pm \mathrm{SD}(\mathrm{N}=3)$. Different lowercase letters in the same set indicate the differences among the treatments at $\mathrm{P}<0.05$.
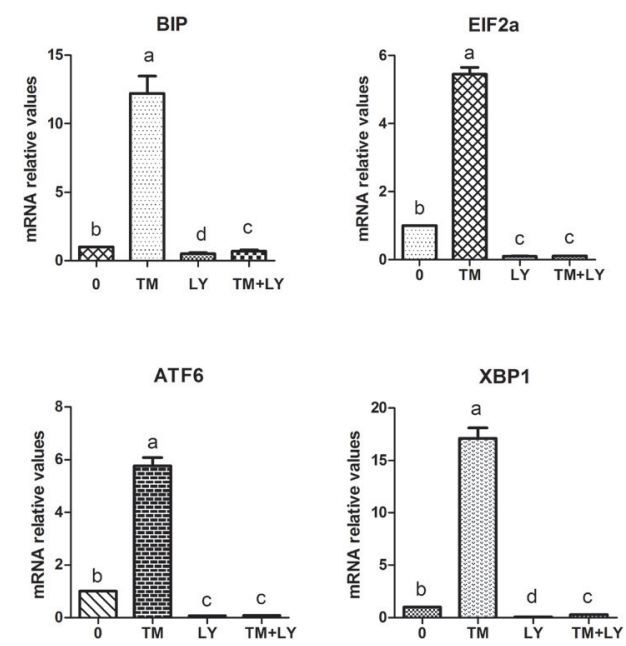

Figure 5. Treatment with LY294002 (LY) abrogated the tunicamycin (TM)-induced ER stress. The mRNA levels were tested by real-time polymerase chain reaction after treatment with $2 \mu \mathrm{M} \mathrm{TM}, 20 \mu \mathrm{M}$ LY294002, or $2 \mu \mathrm{M}$ TM in combination with $20 \mu \mathrm{M}$ LY294002 for $24 \mathrm{~h}$. The expression of genes without any treatment was normalized to a value of 1 . Different lowercase letters in the same set indicate the differences among the treatments at $\mathrm{P}<0.05$. 


\section{Rapamycin abolished TM-induced ER stress}

To test the hypothesis that the regulation of ER stress was connected to the mTOR signaling pathway, the key genes of ER stress were evaluated in cells treated with TM and the mTOR signaling inhibitor, rapamycin. As shown in Figure 6, after the combined treatment with $2 \mu \mathrm{M}$ TM and $30 \mathrm{nM}$ rapamycin, the mRNA levels of genes were significantly lower than in the treatment with $2 \mu \mathrm{M}$ TM alone. These results indicated that rapamycin abolished the TM-induced ER stress and that the mTOR signaling pathway might down-regulate ER stress in the goose primary hepatocytes.
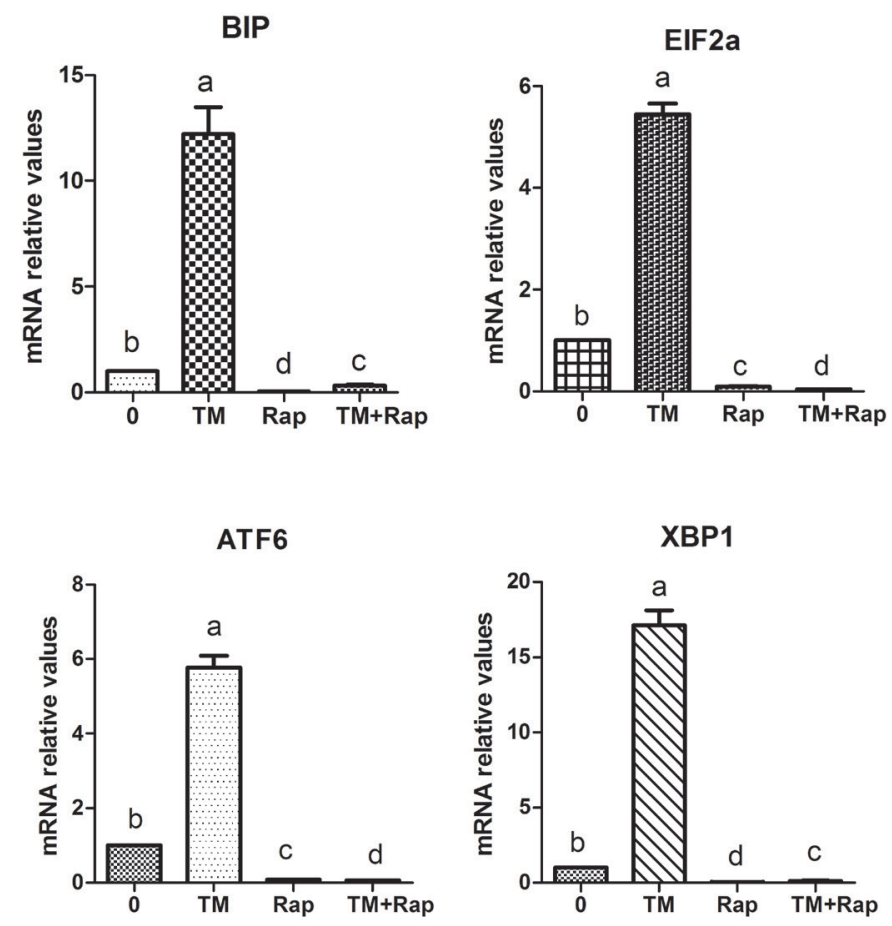

Figure 6. Treatment with rapamycin (Rap) abolished the tunicamycin (TM)-induced ER stress. The mRNA levels were tested by real-time polymerase chain reaction after treatment with $2 \mu \mathrm{M} \mathrm{TM}, 30 \mathrm{nM}$ rapamycin, or $2 \mu \mathrm{M}$ $\mathrm{TM}$ and $30 \mathrm{nM}$ rapamycin together for $24 \mathrm{~h}$. The expression of genes without the addition of any treatment was normalized to a value of 1 . Different lowercase letters in the same set indicate the differences among the treatments at $\mathrm{P}<0.05$.

\section{NVP-BEZ235 prevented TM-induced ER stress}

To determine whether the inhibition of both PI3K and mTOR signaling affected the regulation of the TM-induced ER stress, the key genes of ER stress were evaluated in cells treated with TM as well as with a dual PI3K and mTOR signaling inhibitor, NVP-BEZ235. As shown in Figure 7, after the combined treatment with $2 \mu \mathrm{M}$ TM and $1000 \mathrm{nM}$ NVP-BEZ235, the mRNA levels of genes were significantly lower than in the treatment with $2 \mu \mathrm{M}$ TM alone. NVP-

Genetics and Molecular Research 15 (3): gmr.15037868 
BEZ235 prevented the effect of TM-induced ER stress Thus, we confirmed that both the PI3K and mTOR signaling pathways might down-regulate ER stress in the goose primary hepatocytes.
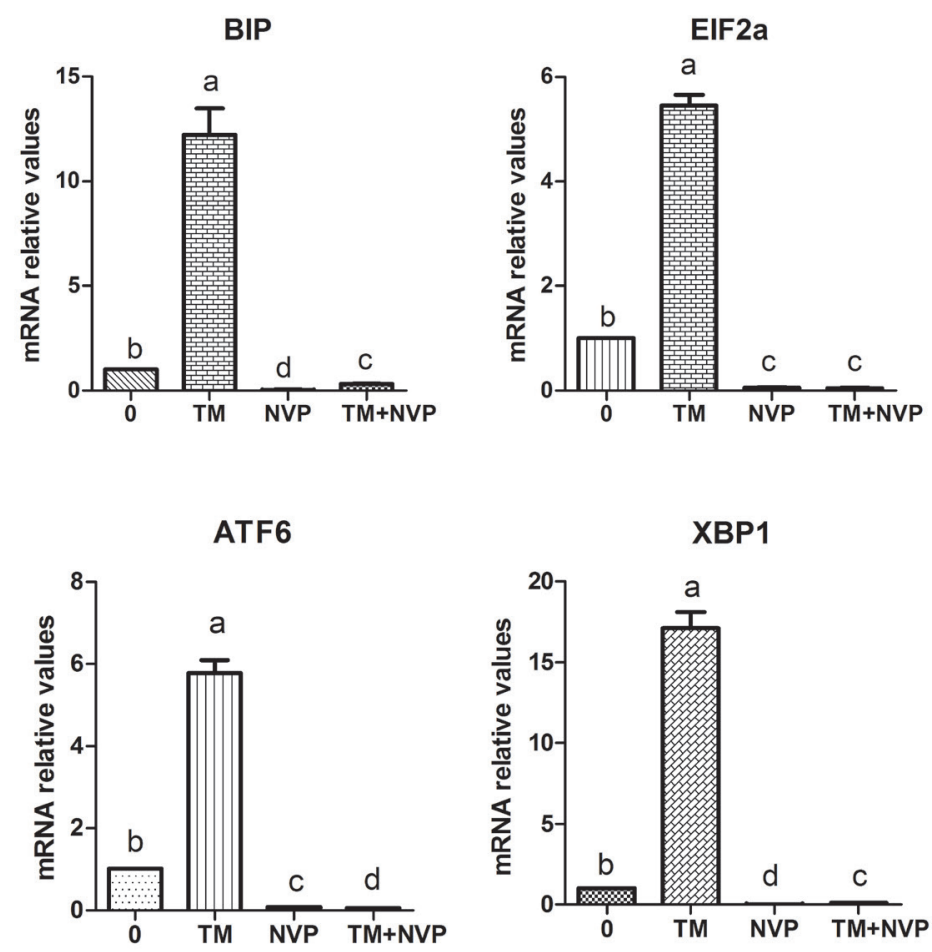

Figure 7. Treatment with NVP-BEZ235 (NVP) prevented the tunicamycin (TM)-induced ER stress. The mRNA levels were tested by real-time polymerase chain reaction after treatment with $2 \mu \mathrm{M} \mathrm{TM}, 1000 \mathrm{nM}$ NVP-BEZ235, or $2 \mu \mathrm{M}$ TM and $1000 \mathrm{nM}$ NVP-BEZ235 together for $24 \mathrm{~h}$. The expression of genes without any treatment was normalized to a value of 1 . Different lowercase letters in the same set indicate the differences among the treatments at $\mathrm{P}<0.05$.

\section{Comparison of relative mRNA levels of genes involved in ER stress after combined treatment with TM and rapamycin, NVP-BEZ235, or LY294002}

To compare the effects of inhibitors of PI3K-AKT-mTOR signaling pathways on ER stress, the mRNA levels of genes involved in ER stress were compared among the combined treatment of TM and PI3K-Akt-mTOR pathway inhibitors (LY294002, NVP-BEZ235, rapamycin, respectively). As shown in Figure 8, after the combined treatment with TM and rapamycin, NVP-BEZ235, or LY294002, there was a similar result with the mRNA expression of $B I P, E I F 2 a, A T F 6$, and XBP1 being decreased in the goose primary hepatocytes $(\mathrm{P}<0.05)$. However, upon combined treatment with TM and LY294002, the mRNA levels of genes were significantly higher than in the combined treatment with TM and NVP-BEZ235 $(\mathrm{P}<0.05)$, but it was not significantly different between the combined treatment with TM and NVP-BEZ235 and combined treatment with TM and rapamycin $(\mathrm{P}>0.05)$. 


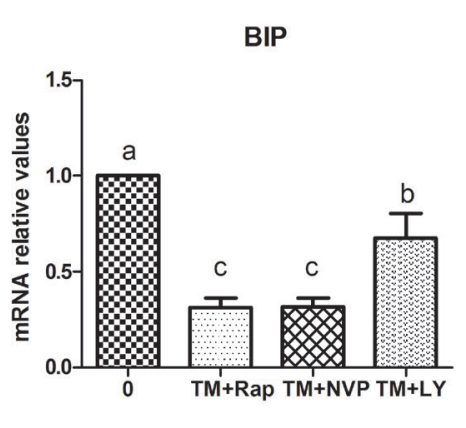

ATF6

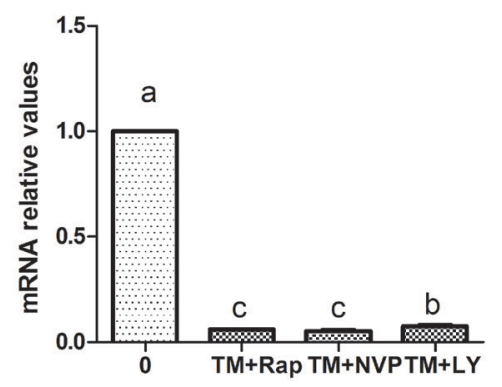

EIF2a

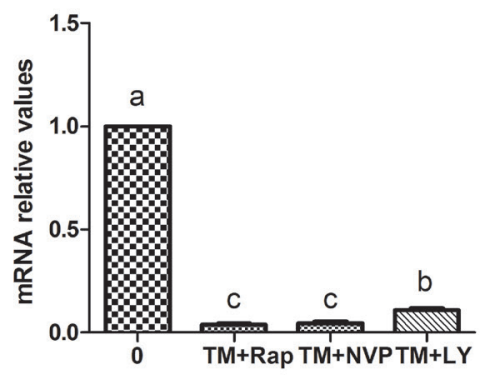

XBP-1

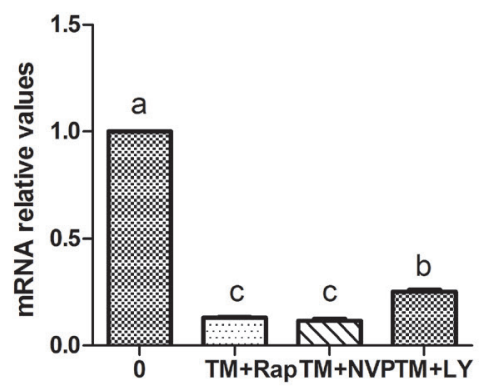

Figure 8. Effect of combined treatment with tunicamycin (TM) and rapamycin (Rap), NVP-BEZ235 (NVP), or LY294002 (LY) on relative mRNA levels of genes involved in ER stress. The mRNA levels were tested by real-time polymerase chain reaction after combined treatment with TM and rapamycin, NVP-BEZ235, or LY294002 for 24 $\mathrm{h}$. The expression of genes without any treatment was normalized to a value of 1 . Different uppercase letters in the same set indicate the differences among the treatments at $\mathrm{P}<0.05$.

\section{DISCUSSION}

ER stress has received growing attention with research suggesting the existence of a close connection between the PI3K-Akt-mTOR signaling pathways and the ER stress (Hosoi et al., 2007). TM inhibits protein glycosylation and is a commonly used ER stress inducer. Our results strongly indicate that TM induced a significant increase in the relative mRNA expression of genes involved in the ER stress in goose primary hepatocytes. This result is consistent with the findings in mouse (Wang et al., 2015) and immortalized human hepatocyte cell model (IHH; Lauressergues et al., 2012).

PI3K/Akt signaling has been reported to be involved in the ER stress (Liu et al., 2013). Previous studies have demonstrated that the activation of Akt signaling pathway might inhibit ER stress (Hu et al., 2004; Mao et al., 2008). However, the detailed mechanism of the PI3K/Akt signaling pathway inhibiting ER stress needs further study. Glucosamine-induced an increase in Akt phosphorylation, which correlated with a large increase in the expression of the endoplasmic reticulum stress marker BIP in astroglial cells (Matthews et al., 2007). On the contrary, Akt activation was unable to alleviate TM-induced ER stress (Liu et al., 2013). In another study, PI3K/Akt inhibition by LY294002 did not suppress ER stress-induced BIP mRNA expression in HEK293 cells. These data indicate that PI3K/Akt does not participate 
in BIP mRNA induction following ER stress (Dai et al., 2010). Compared to cells exposed to thapsigargin-induced ER stress alone, $\mathrm{SKBr} 3$ cells treated with thapsigargin following the treatment with LY294002 and after co-treatment with NVP-BEZ235, did not show significant activation of UPR (Kumandan et al., 2013). To verify whether the PI3K/Akt signaling pathway down-regulated the ER stress in the goose primary hepatocytes, these hepatocytes were co-treated with TM and the PI3K/Akt inhibitor LY294002, or with TM and the PI3K/ mTOR dual inhibitor NVP-BEZ235. The results obtained indicated that inhibiting PI3K/Akt signal pathway could decrease the TM-induced increase in the mRNA expression of genes involved in the ER stress (Figure 5). Co-treatment with TM and NVP-BEZ235 had a similar result as that obtained with the co-treatment of TM and LY294002 (Figure 7); both these treatments decreased the TM-induced increase in the mRNA expression of genes involved in the ER stress. However, the degree of decrease with TM and NVP-BEZ235 co-treatment was significantly higher than the in the TM and LY294002 co-treatment (Figure 8). Overall, the results of the present study indicated that LY294002 abrogated the effect of TM-induced ER stress and suggested that the PI3K signaling pathway might down-regulate the ER stress in goose primary hepatocytes.

Moreover, activation of mTORC1 by deletion of TSC1 or TSC2 has been shown to activate the ER stress response (Ozcan et al., 2008) and mTORC1 signaling is primarily mediated via the regulation of various factors involved in translation (Zoncu et al., 2011; Pópulo et al., 2012). The mRNA levels of BIP and XBP1 were increased, which was observed in vehicle-fed rats and the presence of rapamycin prevented this increase. These data provide evidence that feeding can activate the IRE1a-XBP1 branch of the UPR in the liver via a rapamycin-dependent mechanism (Pfaffenbach et al., 2010). Another important set of findings was that the activation of AMPK down-regulated the mTORC1 activity and attenuated the UPR in vivo, and administration of the mTORC1-specific inhibitor rapamycin suppressed the high glucose-induced ER stress response (Li et al., 2014b). On the contrary, Hwang et al. (2012) found that the inhibition of mTOR by rapamycin had no effect on the ER-stress markers in L6 myotubes. These observations suggest that the mTOR signal pathway does not always have relationships with the ER stress. To detect whether the ER stress was connected to the mTOR signaling pathway in goose hepatocytes, the key genes of ER stress were evaluated in cells co-treated with TM and the mTOR signaling inhibitor, rapamycin and also in cells co-treated with TM and the PI3K/mTOR dual inhibitor, NVP-BEZ235. Our results indicated that the mTOR signal pathway could decrease the TM-induced increase in mRNA expression of genes involved in the ER stress (Figure 6). This result is consistent with the findings of Li et al. (2014a), who showed that rapamycin inhibits light-induced ER stress and dithiothreitol-induced ER stress in $661 \mathrm{~W}$ cells. The result of co-treatment with TM and NVP-BEZ235 was similar with the co-treatment with TM and rapamycin (Figure 7), and both the co-treatments decreased the TM-induced increase in mRNA expression of genes involved in the ER stress. However, there was no significant difference between the two co-treatments (Figure 8). Overall, the results of the present study indicated that rapamycin abolished the effect of TM-induced ER stress and suggested that the mTOR signaling pathway might downregulate the ER stress in goose primary hepatocytes.

Besides, our results indicated that LY294002, rapamycin, and NVP-BEZ235 downregulated the TM-induced increase in mRNA levels of genes involved in the ER stress (BIP, $E I F 2 a, A T F 6$, and XBP1) in goose primary hepatocytes. In summary, inhibiting the PI3K-AktmTOR pathway can prevent TM-induced ER stress. There was no significant difference in

Genetics and Molecular Research 15 (3): gmr.15037868 
inhibition caused by rapamycin and NVP-BEZ235 treatment, This result might have been due to the competitive inhibition effect of NVP-BEZ235, an observation consistent with that of Kong and Yamori (2010) who reported that NVP-BEZ235 and ATP were competitive inhibitors of $\mathrm{mTOR}$ and PI3K, but caused more reactive inhibition of mTOR. but the inhibition resulting from the treatment with LY294002 was significantly different.

In summary, the mRNA levels of genes involved in ER stress (BIP, EIF2a, ATF6, and $X B P 1$ ) were increased after the TM treatment in primary goose hepatocytes. However, this increase was down-regulated by PI3K-Akt-mTOR pathway inhibitors (LY294002, NVP-BEZ235, and rapamycin). Therefore, our results strongly indicate that the PI3K-AktmTOR signaling pathway might down-regulate the TM-induced ER stress in primary goose hepatocytes.

\section{Conflicts of interest}

The authors declare no conflict of interest.

\section{ACKNOWLEDGMENTS}

Research supported by the National Natural Science Funds of China (\#31101712) and the Research Fund for the Doctoral Program of Higher Education of China (\#20115103120006).

\section{REFERENCES}

Dai RY, Chen SK, Yan DM, Chen R, et al. (2010). PI3K/Akt promotes GRP78 accumulation and inhibits endoplasmic reticulum stress-induced apoptosis in HEK293 cells. Folia Biol. 56: 37-46.

Darling NJ and Cook SJ (2014). The role of MAPK signalling pathways in the response to endoplasmic reticulum stress. Biochim. Biophys. Acta 1843: 2150-2163. http://dx.doi.org/10.1016/j.bbamcr.2014.01.009

Flamment M, Hajduch E, Ferré P and Foufelle F (2012). New insights into ER stress-induced insulin resistance. Trends Endocrinol. Metab. 23: 381-390. http://dx.doi.org/10.1016/j.tem.2012.06.003

Galligan JJ, Smathers RL, Shearn CT, Fritz KS, et al. (2012). Oxidative stress and the ER stress response in a murine model for early stage alcoholic liver disease. J. Toxicol. 2012: 207594. http://dx.doi.org/10.1155/2012/207594.

Hendershot LM (2004). The ER function BiP is a master regulator of ER function. Mt. Sinai J. Med. 71: 289-297.

Hosoi T, Hyoda K, Okuma Y, Nomura Y, et al. (2007). Akt up- and down-regulation in response to endoplasmic reticulum stress. Brain Res. 1152: 27-31. http://dx.doi.org/10.1016/j.brainres.2007.03.052

Hu P, Han Z, Couvillon AD and Exton JH (2004). Critical role of endogenous Akt/IAPs and MEK1/ERK pathways in counteracting endoplasmic reticulum stress-induced cell death. J. Biol. Chem. 279: 49420-49429. http://dx.doi. org/10.1074/jbc.M407700200

Hwang SL, Li X, Lee JY and Chang HW (2012). Improved insulin sensitivity by rapamycin is associated with reduction of mTOR and S6K1 activities in L6 myotubes. Biochem. Biophys. Res. Commun. 418: 402-407. http://dx.doi. org/10.1016/j.bbrc.2012.01.038

Kong DX and Yamori T (2010). ZSTK474, a novel phosphatidylinositol 3-kinase inhibitor identified using the JFCR39 drug discovery system. Acta Pharmacol. Sin. 31: 1189-1197. http://dx.doi.org/10.1038/aps.2010.150

Kumandan S, Mahadevan NR, Chiu K, DeLaney A, et al. (2013). Activation of the unfolded protein response bypasses trastuzumab-mediated inhibition of the PI-3K pathway. Cancer Lett. 329: 236-242. http://dx.doi.org/10.1016/j. canlet.2012.11.014

Lai MT, Huang KL, Chang WM and Lai YK (2003). Geldanamycin induction of grp78 requires activation of reactive oxygen species via ER stress responsive elements in 9L rat brain tumour cells. Cell. Signal. 15: 585-595. http:// dx.doi.org/10.1016/S0898-6568(03)00004-4

Lauressergues E, Bert E, Duriez P, Hum D, et al. (2012). Does endoplasmic reticulum stress participate in APDinduced hepatic metabolic dysregulation? Neuropharmacology 62: 784-796. http://dx.doi.org/10.1016/j. neuropharm.2011.08.048

Genetics and Molecular Research 15 (3): gmr.15037868 
Li GY, Fan B and Jiao YY (2014a). Rapamycin attenuates visible light-induced injury in retinal photoreceptor cells via inhibiting endoplasmic reticulum stress. Brain Res. 1563: 1-12. http://dx.doi.org/10.1016/j.brainres.2014.02.020

Li H, Min Q, Ouyang C, Lee J, et al. (2014b). AMPK activation prevents excess nutrient-induced hepatic lipid accumulation by inhibiting mTORC1 signaling and endoplasmic reticulum stress response. Biochim. Biophys. Acta 1842: 18441854. http://dx.doi.org/10.1016/j.bbadis.2014.07.002

Liu CM, Zheng GH, Ming QL, Sun JM, et al. (2013). Protective effect of quercetin on lead-induced oxidative stress and endoplasmic reticulum stress in rat liver via the IRE1/JNK and PI3K/Akt pathway. Free Radic. Res. 47: 192-201. http://dx.doi.org/10.3109/10715762.2012.760198

Livak KJ and Schmittgen TD (2001). Analysis of relative gene expression data using real-time quantitative PCR and the $2^{-\Delta \Delta \mathrm{Ct}}$ method. Methods 25: 402-408. http://dx.doi.org/10.1006/meth.2001.1262

Mao W, Iwai C, Liu J, Sheu SS, et al. (2008). Darbepoetin alfa exerts a cardioprotective effect in autoimmune cardiomyopathy via reduction of ER stress and activation of the PI3K/Akt and STAT3 pathways. J. Mol. Cell. Cardiol. 45: 250-260. http://dx.doi.org/10.1016/j.yjmcc.2008.05.010

Matthews JA, Belof JL, Acevedo-Duncan M and Potter RL (2007). Glucosamine-induced increase in Akt phosphorylation corresponds to increased endoplasmic reticulum stress in astroglial cells. Mol. Cell. Biochem. 298: 109-123. http:// dx.doi.org/10.1007/s11010-006-9358-5

Ozcan U, Ozcan L, Yilmaz E, Düvel K, et al. (2008). Loss of the tuberous sclerosis complex tumor suppressors triggers the unfolded protein response to regulate insulin signaling and apoptosis. Mol. Cell 29: 541-551. http://dx.doi. org/10.1016/j.molcel.2007.12.023

Pagliassotti MJ (2012). Endoplasmic reticulum stress in nonalcoholic fatty liver disease. Annu. Rev. Nutr. 32: 17-33. http:// dx.doi.org/10.1146/annurev-nutr-071811-150644

Pfaffenbach KT, Nivala AM, Reese L, Ellis F, et al. (2010). Rapamycin inhibits postprandial-mediated X-box-binding protein-1 splicing in rat liver. J. Nutr. 140: 879-884. http://dx.doi.org/10.3945/jn.109.119883

Pópulo H, Lopes JM and Soares P (2012). The mTOR signalling pathway in human cancer. Int. J. Mol. Sci. 13: 1886-1918. http://dx.doi.org/10.3390/ijms13021886

Rao RV, Ellerby HM and Bredesen DE (2004). Coupling endoplasmic reticulum stress to the cell death program. Cell Death Differ. 11: 372-380. http://dx.doi.org/10.1038/sj.cdd.4401378

Schröder M and Kaufman RJ (2005a). ER stress and the unfolded protein response. Mutat. Res. 569: 29-63. http://dx.doi. org/10.1016/j.mrfmmm.2004.06.056

Schröder M and Kaufman RJ (2005b). The mammalian unfolded protein response. Annu. Rev. Biochem. 74: 739-789. http://dx.doi.org/10.1146/annurev.biochem.73.011303.074134

Seglen PO (1976). Preparation of isolated rat liver cells. Methods Cell Biol. 13: 29-83. http://dx.doi.org/10.1016/S0091$\underline{679 X(08) 61797-5}$

Shen X, Zhang K and Kaufman RJ (2004). The unfolded protein response--a stress signaling pathway of the endoplasmic reticulum. J. Chem. Neuroanat. 28: 79-92. http://dx.doi.org/10.1016/j.jchemneu.2004.02.006

Wang H, Wang X, Ke ZJ, Comer AL, et al. (2015). Tunicamycin-induced unfolded protein response in the developing mouse brain. Toxicol. Appl. Pharmacol. 283: 157-167. http://dx.doi.org/10.1016/j.taap.2014.12.019

Yuan Y, Guo Q, Ye Z, Pingping X, et al. (2011). Ischemic postconditioning protects brain from ischemia/reperfusion injury by attenuating endoplasmic reticulum stress-induced apoptosis through PI3K-Akt pathway. Brain Res. 1367: 85-93. http://dx.doi.org/10.1016/j.brainres.2010.10.017

Zoncu R, Efeyan A and Sabatini DM (2011). mTOR: from growth signal integration to cancer, diabetes and ageing. Nat. Rev. Mol. Cell Biol. 12: 21-35. http://dx.doi.org/10.1038/nrm3025

Genetics and Molecular Research 15 (3): gmr.15037868 